\title{
FOOD SUPPLY AND NUTRITION IN THE BULGARIAN ARMY
}

\author{
Pavlin GLUSHKOV \\ "Vasil Levski” National Military University, Veliko Tarnovo, Bulgaria \\ pavlin_glushkov@mail.bg
}

\begin{abstract}
The main tasks of food logistics in the military formations are to provide the personnel with food, material and nutritional property, to maintain and refresh the stocks, as well as organize the nutrition of the personnel in peacetime and wartime according to the current nutrition norms.

It should be noted that food supply and the organization of nutrition bear its specific characteristics depending on the place where it is carried out and the force of the factors that influence it.

The present study focuses on the organization of nutrition in the stage of peacetime national training of military forces.
\end{abstract}

KEYWORDS: Bulgarian Army, Logistics, Supply, Military Diet

\section{Introduction}

The provision of food and nutrition of the Bulgarian Army formations is a continuous daily process implemented by the logistic authorities.

The organs of the material and technical facilities of the food supply, the nomenclature, the sources and means of obtaining the material means, the manner of their delivery to the military units and to the individual servicemen, the rules for maintenance, consumption and reporting give an idea of the organization of food supply (Food Supply of the military units in peacetime, 1980).

The physical capability of the servicemen, respectively the combat readiness of the military formations, is directly dependent on the timely provision of quality food to the eligible servicemen. This process is related to the planning, implementation and control of its constituent activities. The implementation of the task of offering quality, ready-to-eat food at a specific time and place is related to the creation of a particular organization of the nutrition.

Providing food for the army is a process that requires the efforts of many officials who need to have appropriate know-how and skills in the field of army nutrition.

\section{Overview of the Current State of} the Organization of Food Supply and Nutrition in the Bulgarian Army

The starting point of the study was the conceptual design of the "Rear" system, which was developed in the 70s of the past century. It regulates the activities of the rear command authorities, the forces and the means, the forms and the principles for securing the Bulgarian army with material and technical provisions in peace and wartime. 
Functionally, the "Rear" system is broken down into subsystems. The subsystem "Supply of food, food technology and property" occupies the leading position.

The provision of food to the employees of the Bulgarian Army is organized in accordance with the terms and conditions for the supply of food, announced in a regulation of the Minister of Defence. Until the beginning of 2015, this was done by an order of the Minister of Defence. The main regulation document of 02.04.2015 is Ordinance No. H-5 on the conditions, procedures and norms for the provision of free food and refreshing drinks for servicemen and civil servants in the Ministry of Defence, the structures in direct subordination to the Minister of Defence and the Bulgarian Army and of the cadets in the higher military schools in peacetime.

The analysis of the Nutrition Ordinance of the Ministry of Defence (MoD) supports the view that the establishment of the necessary organization and control of the provision of free food to the entitled persons requires:

1. The commanders of military formations providing free food should approve a weekly menu.

The weekly menu is based on the recommended composition of the main food products listed in the relevant regulations. The cost of the food products included in the weekly menu shall not exceed the monetary values specified in a separate annual order of the Minister of Defence. When preparing the weekly menu, it is mandatory to observe the energy and material norms for balanced nutrition.

2. The granting/revoking of free food to be made by order of the commander.

3. Free food is provided according to different norms and with different energy value to the eligible persons.

The categories of servicemen and civil servants entitled to free food under different standards of nutrition are provisionally grouped as follows: servicemen and civil servants: from the navigation crew of ships, aviation, engineering and technical staff, parachutists, guards and duty officers from the National Guards Section, cadets and duty officers from the higher military schools;

$>$ servicemen and civil servants - divers;

$>$ servicemen and civil servants - flight crew;

$>$ servicemen and civil servants that are not listed in the above categories.

It ought to be taken into account that the unification of food norms and the use of a few rationally developed food rations, intended for the main armed forces, create a number of conveniences for the supply of food to the troops. The particularities of nutrition, which must be taken into account in respect of some military specialties, should be satisfied through specially targeted additional rations, the grant of which is in the form of supplements in addition to the general unified ration for the Bulgarian Army (Stavrev, Sheytanov \& Donev, 1969).

The fact that it is important to determine the relevant nutrition norms bearing on the rational and protective professional nutrition is indicative in this respect. "Regardless of the method of their development, the norms for the quantities of food products are indicative values for characterizing a nutritional fund which, when appropriately distributed, can satisfy the nutritional needs of each person in a team" (Rational and prophylactic professional diet, 1974). In his study, Nichev (2017b) deals with the problems of determining an individual's energy needs and "converting" the need for energy into food.

4. Disposable single-use receptacles shall be provided to persons entitled to food outside of stationary food establishments, outside the points of permanent basing of ships and at the discretion of commanders, subject to specific conditions in order to comply with hygiene requirements. 
5. The control of delivered food products, their storage, the preparation, supply and quality of free food, supplements and refreshing beverages should be carried out in accordance with the Food Law, the Law on Veterinary Medicine and the secondary legislation issued for their implementation, the Statute for the Armed Forces Service of the Republic of Bulgaria and the contracts concluded under the Public Procurement Act.

Control is a management function that underpins the quality assurance process of outsourcing services such as supply of food products or corporate meals. Stefanov defines the contracts related to the nutrition of the servicemen as an essential part of the outsourcing activity in the Ministry of Defence (Stefanov, 2017a). In his study Nichev (2017a) outlines as a possible risk in outsourcing contracts the lower or nonconforming quality as compared to what has been agreed, which in turn is related to the exercise of control by the contracting authority.

6. Samples of the ready meal in a size of one portion of each type of dish shall be allocated and stored in accordance with the Military Service Statute of the Armed Forces of the Republic of Bulgaria immediately prior to the distribution of the ready-to-eat food.

The food is prepared in a stationary kitchen separately for breakfast, lunch and dinner. The provision of freshly cooked food to the military formations that have completed training sessions, teachings and camps is carried out by the deployment of field food facilities equipped with field food equipment and property.

A basic requirement for the food is that it is diverse, nutritious and rich in calories to secure the energy needs required by the body of the servicemen when performing their duties in conditions of training and combat activities.

The known forms of planning and provision of ready-to-eat food are given in the form of a table or value. The currently used form of food provision is the one expressed in terms of value. The table form of food provision has not been in operation since 2002, but for the sake of development, it is necessary to clarify the essence of its concept.

Some mandatory rules for the composition of the daily ration have been announced on the basis of the scientifically valid norms arrived at after some studies (in the 70s of the last century [Irinkov, Kolev, 2012]) that have been carried out among the servicemen from the mass Bulgarian Army on their energy consumption and, respectively, their need for nutrients by categories and under different working conditions. This contributes to the guaranteed intake of specific proteins, fats, carbohydrates, vitamins, minerals, fiber and other nutrients. What is typical for the table form of food supply is the breakdown of the daily table into the composition of the daily ration with products listed in a weekly menu - a breakdown by day, meals and weight of meals. The requirement for the proportion of meat, dairy, fresh fruit and vegetables, potatoes, cereals and canned foods is strictly observed. The main emphasis is placed on the use of a table of substitutes in order to preserve the energy value and composition of the main nutrients in the menu in the absence of some food products from the daily menu in the Military Formation Warehouse.

A number of specialists share the belief that eating standards represent average amounts of nutrients and energy that best meet the needs of the different types of military troops. In line with the level of scientific knowledge, the following requirements shall apply: the quantity, i.e. the calorie value of daily rations should provide $10 \%$ energy in excess of the energy consumption, it should be biologically whole; i.e. contain all the nutrients necessary for the organism in optimal quantities and proportions, it 
should be digestible and well digested and be varied in terms of the composition of the products. For those categories of servicemen working under conditions of great physical and nervous tension or under the influence of adverse factors, an additional requirement is imposed on the diets - to influence the normalization of the disturbed physiological state and to contribute to increasing the body's resistance to the respective unfavourable influences (Stavrev, Sheytanov \& Donev, 1969).

By Order of the Minister of Defence No. OX - 825/09.12.2002, the value norms of nutrition are introduced and a company meal is allowed to be offered through a line of command. The internal regulations in the MoD stipulate that the unused food products for the month should not exceed an average of $1 \%$ of the value of one day ration. At the same time, the mandatory requirement for achieving the energy and material norms for balanced nutrition is in force.

It should be noted that the table on the composition of the daily ration is now recommended and not mandatory.

Obviously, the new imperatives of "high-value nutrition" lead to imbalances in the proportions of major nutrients that should be present in the daily menu. This is so because nutritionists calculate their menus to "the last penny" and the portions of meals are influenced by the change in supply prices. According to the signed contracts, the prices of the food products are updated every month, in line with the data provided by the state system for agromarket information.

A prerequisite for organizing the process of food provision in the military formation is to have the following established, assigned and secured: Units responsible for planning, managing and controlling the provision of food; implementing bodies (manufacturing bodies); reporting officers; appropriate infrastructure; food equipment and property; sources of supply of food and developed nutrition regulations. An essential condition for achieving the main objective of food logistics, namely the supply of ready-to-eat food to consumers, is the storage of food products under appropriate conditions. This, in turn, corresponds to a number of processes, conditions and risks associated with the Army warehouse, which have been studied by some Bulgarian scientists (Banabakova, Filipov \& Stoyanov, 2017).

The organization of food provision and nutrition depends on the specific operational and tactical situation (Kaloyanov, 2003). This gives grounds to define food provision and nutrition as a continuous, intricate process in terms of organization and implementation that includes:

a subsystem for the supply of food products;

stocking supplies of food, food equipment and property;

- Storage and distribution of stocks;

$>$ preparation of freshly cooked food in stationary and field conditions;

$>$ distribution and delivery to the subdivisions, end-users;

$>$ forming and maintaining optimal forces and means to implement this uninterrupted process.

The main planning document for food provision is the weekly menu. The weekly menu is prepared on the basis of the currently active regulations on food provision for one servicemen (by categories of servicemen) depending on the activities he performs and the conditions under which they are performed.

The organization of nutrition, according to the influence of the criteria conditions of implementing the assigned tasks of the formation and the dynamics of the operational and tactical environment, can be classified as follows:

organization of nutrition under stationary conditions; 
organization of nutrition under field conditions;

$>$ organization of nutrition in peacetime conditions;

$>$ organization of nutrition in peacetime conditions;

$>$ organization of nutrition in wartime conditions;

Food provision stations are deployed in accordance with the theory of food preparation and its supply in field conditions and providing staff with bread and drinking water in the battalions (divisions) and other formations, which have the allocated resources to prepare food. Formations that do not have sufficient resources to do so, with the permission of the deputy commander of logistics, are attached to formations deploying food station in order to secure their provision of food. Baking of bread is done in field bakeries or in local bakeries. Delivery of bread to the formations is done centrally. The provision of military formations with water includes the following: reconnaissance of water sources, manners of obtaining it and purification methods; construction and security of water supply stations; water storage and distribution; replenishment of the water stocks (Food supply of the military divisions in peacetime, 1980).

Food should be prepared in strict compliance with the nutrition requirements for out-of-barracks accommodation of troops.

The possibilities of preparing any kind of meal using field food equipment is limited due to the constructional features of the production machines, mainly preparing a meal through boiling.

The level of experience and training of the nutritionists and the composition of the team of nutritionists is essential to meeting the nutrition goals.

A study of the nutrition documentation in the MoD outlines the following methods of preparing food:

1. Army food provision - food preparation by the kitchen staff in full-time employment, with the food products supplied by an external contractor.

This method is dependent on the supply of food products under the terms of the Public Procurement Act. In this case, there is a risk of delay due to appeals on the procedure by bidders. At this stage, this gives grounds to identify this method as unsustainable and with a high degree of risk. However, it should be emphasized that this is the method of food provision, which gives one of the characteristics that define the autonomy and the combat capability of a military formation.

2. Organization of food provision by an external contractor - preparation of food under contracts for the execution of a public procurement for food provision (company meal). The nature of this method and the research of a number of scholars (Stefanov, 2017b) defines it as a classical form of outsourcing service with proven economic efficiency compared to the Army food provision method.

3. Payment of the cost of free food, supplements and refreshing drinks to servicemen. The emergence and validation of this method is the result of the procedural difficulties in implementing food provision for the army.

4. Food provision under the signed memorandums or other international arrangements, a method which is applicable to the provision of food for soldiers participating in missions, operations and exercises outside the territory of the Republic of Bulgaria.

Periodic studies of the nutritional status of forces sent abroad allow for the identification of existing imbalances and correlations with certain diseases (Glushkov, 2017a). The results obtained could be the basis for developing new nutrition standards for special contingent soldiers with the tools of mathematical modelling (Glushkov, 2017b).

5. Setting up of canteens with reimbursement of expenses incurred by the 
servicemen using the canteen. This method is aimed at satisfying the needs of servicemen and civil servants who are not entitled to free meals. In the absence of a contract for the supply of foodstuffs for the needs of the Army food provision method, canteens can cater for the needs of those entitled to free food. It ought to be clarified that this method does not replace the former, since the system of canteens with reimbursement of expenses incurred by the servicemen using the canteen is not developed to such an extent as to be extended to all military formations.

The supply of food, foodstuffs and food equipment is carried out in different ways, which are used depending on the classification of the supply according to the following characteristics:

$>$ Depending on the source of supply: from own warehouses and facilities, from warehouses and facilities of the Logistics brigade, from redistribution between the types of armed forces and military formations, from external companies and organizations;

depending on the procuring entity through which the supply is carried out: centralized supply - for material resources and services acquired through the unified financial plan for material and technical support of the Ministry of Defence for which the Minister of Defence is the contracting authority; decentralized supply - for material resources and services acquired through implemented procedures for which the contracting authority is the second-line authorizing officers for budget credits, legal entities; depending on the transport procurement: using the transport of the assignor/final recipient; using the transport of the provider and/or the procurement contractor; with international transport in accordance with the agreements with NATO and the coalition partners;

depending on the geographic location of the formations receiving the food supply: regional/zonal - on the territory of the country, territorial on the territory of the country, international - outside the territory of the country.

The organization of the logistic support (provision), respectively food provision, in theoretical terms, was examined by Nichev, taking into account the specifics of the military logistics (Nichev, 2011).

\section{Conclusion}

The degree of impact of surrounding factors on the logistics operations, in some cases, determines the differences in the organization of food provision. The Army food provision method alone is applicable to all conditions of implementing the assigned tasks of the military formations and to any dynamics of the operationaltactical situation.

Regardless of the diverse and complex composition of the material resources and services in the defence, their provision is carried out through defencebased planning dependent on capabilities, with the planning, programming and budgeting system being applicable for this purpose. 


\section{REFERENCES}

Banabakova, V., Filipov, S., \& Stoyanov, S. (2017). State and Problems of Warehousing of Bulgarian Army, The $23^{\text {rd }}$ International Conference Knowledge-Based Organization, Volume XXIII, No. 2, 9-15.

Food provision for the troops in peacetime. (1980). Sofia: Military Publishing House.

Glushkov, P. (2017a). A study of nutrition and the nutritional status of servicemen, assessed on the basis of anthropometric indicators, The $23^{\text {rd }}$ International Conference Knowledge-Based Organization, Volume XXIII, No. 2, 298-302.

Glushkov, P. (2017b). Use of linear optimization model in defining the new standards for the preparation of food for servicemen in preparation for participation in peacekeeping operations, The $23^{\text {rd }}$ International Conference Knowledge-Based Organization, Volume XXIII, No. 2, 65-70.

Irinkov, V., \& Kolev, N. (2012). Problems of the food provision for servicemen in modern operations and directions for solving them, Military Journal, 2.

Kaloyanov, I. (2003). Fundamentals of food security and nutrition of the Bulgarian military personnel in peacetime and participation in peacekeeping operations. Sofia: Textbook.

Nichev, N. (2011). Theoretical foundations of military logistics - organization of logistical support, V. Tarnovo, BG: Vasil Levski National Military University.

Nichev, N. (2017a). Risk Management in the Decision Making Process Concerning the Use of Outsourcing Services in the Bulgarian Armed Forces, The $23^{\text {rd }}$ International Conference Knowledge-Based Organization, Volume XXIII, No. 2, 405-410.

Nichev, N. (2017b). Possibility for Improving the Planing of the Needs of Food from Bulgarian Army Units When Participating in Humanitarian Operations, Revista Academiei Fortelor Terestre, Vol. XXII, Nr. 1(85), 18-24. Education.

Rational and prophylactic professional diet. (1974). Sofia: Medicine and Physical

Stavrev, P., Sheytanov, M., \& Donev, D. (1969). Military hygiene, Sofia, BG: Ministry of Defence.

Stefanov, N. (2017a). Analysis of the Use of Outsourcing Services for Maintenance and Repair of the Equipment and Armament Available in the Structures of the Bulgarian Armed Forces, The $23^{\text {rd }}$ International Conference Knowledge-Based Organization, Volume XXIII, No. 1, 467-472.

Stefanov, N. (2017b). Analysis of Some of the Applicable Outsourcing Services in the Structures of the Bulgarian Armed Forces, The $23^{\text {rd }}$ International Conference KnowledgeBased Organization, Volume XXIII, No. 1, 473-478. 